\title{
Electrochemical Reduction of Nitrate and Nitrite in Concentrated Sodium Hydroxide at Platinium and Nickel Electrodes
}

by

D. T. Hobbs

E. I. du Pont de Nemours and Company

Savannah River Site

Aiken, South Carolina 29808

H. L. Li

University of Tennessee

TN USA

D. H. Robertson

University of Tennessee

TN USA

J. Q. Chambers

University of Tennessee

TN USA

\section{DISCLAIMER}

\begin{abstract}
This report was prepared as an account of work sponsored by an agency of the United States Government. Neither the United States Government nor any agency thereof, nor any of their employees, makes any warranty, express or implied, or assumes any legal liability or responsibility for the accuracy, completeness, or usefulness of any information, apparatus, product, or process disclosed, or represents that its use would not infringe privately owned tights. Reference herein to any specific commercial product, process, or service by trade name, trademark, manufacturer, or otherwise does not necessarily constitute or imply its endorsement, recommendation, or favoring by the United States Government or any agency thereof. The views and opinions of authors expressed herein do not necessarily state or reflect those of the United States Government or any agency thereof.
\end{abstract}

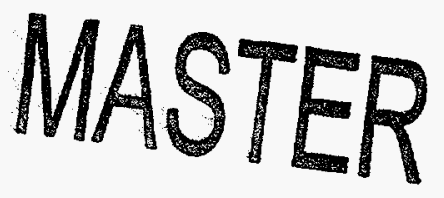

DOE Contract No. DE-AC09-89SR18035

This paper was prepared in connection with work done under the above contract number with the U. S.

Department of Energy. By acceptance of this paper, the publisher and/or recipient acknowledges the U.S. Government's right to retain a nonexclusive, royalty-free license in and to any copyright covering this paper, along with the right to reproduce and to authorize others to reproduce all or part of the copyrighted paper.

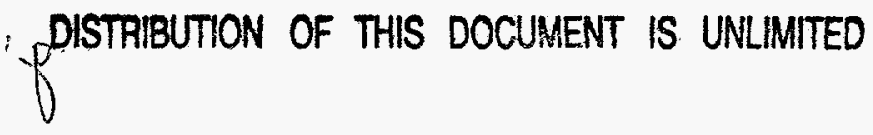




\section{DISCLAIMER}

Portions of this document may be illegible in electronic image products. Images are produced from the best available original document. 
ELECTROCHRMTCAL RRDUCTION OF MITRATS AND NITRITE IR CONCENTRATED SODIOM GYDROXIDE AT PLATINIUM AND MICRBL BLECTRODBS

by

Hu-lin-Li, Daniel H. Robertson, and James Q. Chambers

Department of Chemiatry

University of Tennessee

Rnoxville, IN 37996

and

D. T. Hobbs

E. I. du Pont de Nemours and Company

Sevannah River Laboratory

Aiken, South Carolina 29808

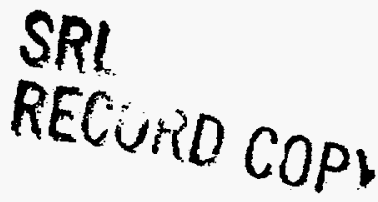

\section{INFORMATION ONLY}

This paper was prepared in connection with work done under Contract No. DE-AC09-76SR00001 with the U.S. Department of Energy. By acceptance of this paper, the publisher and/or recipient acknowledges the U.S. Governwent's right to retain a nonexclusive, royalty-free license in and to any copyright covering this paper, along with the right to reproduce and to authorize others to reproduce all or part of the copyrighted paper. 


\section{DISCLAIMER}

This report was prepared as an account of work sponsored by an agency of the United States Government. Neither the United States Government nor any agency thereof, nor any of their employees, makes any warranty, express or implied, or assumes any legal liability or responsibility for the accuracy. completeness, or usefulness of any information, apparatus, product, of process disclosed, or represents that its use would not infringe privately owned rights. Reference herein to any specific commercial product, process, or service by trade name, trademark, manufacturer, or otherwise does not necessarily constitute or imply its endorsement, recommendation, or favoring by the United States Government or any agency thereof. The views and opinions of authors expressed herein do not necessarily state or reflect those of the United States -Government or any agency thereof.

This report has been reproduced directly from the best available copy.

Available to DOE and DOE contractors from the Office of Scientific and Technical Information. P. O. Box 62, Oak Ridge, TN 37831; prices available from (615) $576-8401$.

Available to the public from the National Technical Information Service. U. S. Department of Commerce, 5285 Por Royal Rd., Springfield. VA 22161 
ELECTROCAEMICAT REDOCTIOK OF NITRATE AND NITRITS IA CONCENTRATED SODIUM HYDROXIDE AT PLATIHIOM AND AICKRL ELBCTRODAS*

by

Hu-lin-Li, ** Daniel H. Robertson, t and James Q. Chambers

t Department of Chemistry University of Tennessee Raoxville, TN 37996

and

D. T, Hobbs

E. I. du Pont de Nemours and Company Savannah River Laboratory Aiken, SC 29808

The present work was undertaken in order to learn more about the electrochemical reduction of nitrate in alkaline solutions. Conditions which maximize the current efficiency for the production of dinitrogen and or ammonia gases

$$
\begin{aligned}
& \mathrm{NO}_{3}^{-}+3 \mathrm{H}_{2} \mathrm{O}^{-}-5 \mathrm{e}^{-} \longrightarrow 1 / 2 \mathrm{~N}_{2}+6 \mathrm{OH}^{-} \\
& \mathrm{NO}_{3}^{-}+6 \mathrm{H}_{2} \mathrm{O}^{-}+8 \mathrm{e}^{-} \longrightarrow \mathrm{NH}_{3}+9 \mathrm{OH}^{-}
\end{aligned}
$$

could have far-reaching significance regarding the treatment of radioactive waste solutions. This has been realized for some time and one patent (1) and several reports in the closed literature $(2,3)$ give conditions for the above processes in two-electrode cells under essentially constant current conditlons. Reduction of nitrate to harmless gases would permit recycling of caustic

* The information contained in this article was developed during the course of work under Contract No. DE-AC09-76SR00001 with the U.S. Department of Energy.

** Rermanent address: Chemistry Department, Lanzhou University, Gansu Province, China. 
electrolysis solutions for the neutralization of nitric acid waste solutions. In this fashion the volume of radioactive waste solution requiring disposal would be reduced.

The reduction of nitrate and nitrite ions at platinized platinum electrodes in IM- NaOt has been studied by Horanyi and Rizmayer (4). These authors found pronounced maxima in the polarization curves and presented coulometric data supporting complete reduction to ammonia at high overpotentials. At less negative potentials reduction to dinitragen $\left(\mathrm{N}_{2}\right)$ was indicated.

In the present study the overall electrode reaction for the reduction of nitrate in alkaline medium has been established under conditions approaching those encountered in actual radioactive waste solutions. Previous applied studies $(1-3)$ have not coneidered the possible effects of the presence of oxygen on the reduction of nitrate. Oxygen gas generated at the anode in these cells is transported to the cathode where it can be reduced and possibly decrease the current efficiency for the cell reaction. Accordingly, in the studies reported below the cathode compartment was isolated from anode by a membrane separator. Furthermore, oxygen was added to the gas stream in the cathode compartment in order to determine its effect on the course of the electrolysis.

\section{Experimental}

Electrodes and Materials.--For voltamietric studies two platinum electrodes with geometric areas of $0.21 \mathrm{~cm}^{2}$ and $0.5 \mathrm{~cm}^{2}$ were used. They were polished with 0.3 micron lapping compound, washed in 1:1 nitric acid, and rinsed thoroughly with distilled

\section{INFORMATION ONLY}


water before use. A nickel disk electrode with an area of ca. $0.2 \mathrm{~cm}^{2}$, which was made from a nickel-200 rod (Huntington Alloys) encased in Teflon, was polished, treated with $1: 1 \mathrm{HCl}$, and washed with distilled water as above. Large ares nickel-200 plate and platinum gauze electrodes were used for the coulometric experiments. Nickel plate electrodes $(3 \mathrm{~cm} \times 2 \mathrm{~cm} \times 0.12 \mathrm{~cm})$ were platinized by simple imersion in a $37 \mathrm{PtCl}_{4} / 0.025 \% \mathrm{~Pb}$ (acetate) 2 solution for ca. 5 min. These electrodes were used extensively for the coulometric experiments describe below. A S.C.E. reference electrode was employed.

Certified A.C.S. grade reagent $\mathrm{NaOH}, \mathrm{Na}_{2} \mathrm{CO}_{3}, \mathrm{NaNO}_{2}$, and $\mathrm{NaNO}_{3}$ (Fisher), the latter two dried at $120^{\circ} \mathrm{C}$, were used to prepare the solutions. The manufacturer specified that the nitrite content in the $\mathrm{NaNO}_{3}$ was 1 ess than $0.001 \%$. High purity nitrogen and oxygen were used to purge the solutions. Metering valves (MC Scientific), flow rates 0.05 to $0.5 \mathrm{~mL} / \mathrm{min}$ and 0.2 to $2.0 \mathrm{~mL} / \mathrm{min}$, were used to provide the gas mixtures.

Instrumentation.--Cyclic voltametry was carried out with a BAS $C V-27$ voltameter and a BAS 100 Electrochenical Analyzer. The controlled potential coulometry was done using a P.A.R. Model $173 / 179$ potentiostat-coulometer. Most of the electrolyses were performed in two-compartment cell with a 0.007 -inch-thick Nefion-117 (Aldrich) membrane separator (area $=1.75 \mathrm{~cm}^{2}$ ). Temperacure control $\left( \pm 2^{\circ} \mathrm{C}\right)$ was achieved using a Sargent chermonitor, model ST S-82052. Mass spectra of the gases produced at the 
cathodes wise obtained by direct injection inco the EI ionization chamber of a Hewlett-Packard model $5934 \mathrm{~A}$ mass spectroneter.

Ion chromatography was performed using a Dionex anion exchange colum? (AS4A) and a carbonate buffer ( $\mathrm{pH} 10,0.2498 \mathrm{~g} \mathrm{NaHCO}_{3}$. $0.8570 \mathrm{~g} \mathrm{Na}_{2} \mathrm{CO}_{3} / 4 \mathrm{~L}$ ) mobile phase, flow rates: $2.00 \mathrm{~mL} / \mathrm{min}$ for nitrate and $1.00 \mathrm{~mL} / \mathrm{min}$ for nitrate/nitrite mixtures. "Optical detection at $202 \mathrm{~nm}$ provided adequate sensitivity for the relatively high concentrations of ions in the electrolysis solutions.

\section{RESULTS}

Bulk Electrolyses.--Constant potential coulometry was performed at platinum, nickel, and platinized nickel electrodes on $\mathrm{NaNO}_{2}, \mathrm{NaNO}_{3}, \mathrm{Na}_{2} \mathrm{CO}_{3}$, $\mathrm{NaOH}$ solutions under a variety of conditions. Results are given in Table 1. The concentration of nitrite and nitrate during the course of the electrolyses was determined by chromatographic analysis as described in the experimental section. Most of the electrolyses were carried out with a divided cell using a Nafion membrane to separate the anodic and cathodic cell compartments.

Eigure 1 shows a typical experiment in wich a nitrite intermediate chromatographic peak appears during the course of an electrolysis. Coulometric current efficiencies based on the fiveelectron reduction to dinitrogen $\left(N_{2}\right)$ were quite high, ranging up to ca. $90 \%$ in some experiments. At short times (Less than $20 \%$ electrolysis) close to $100 \%$ current efficiencies were obtained. In most of the electrolyses a nitrite intermediate peak was evident, 
although further reduction was always observed. No other peaks appeared in the ion chromatograms.

Qualitative identification of $\mathrm{N}_{2}$ as the major electrolysis product was achieved by mass spectroscopy. In these experiments the cathode was inserted in an inverted collection tube in guiet solution. The gas produced at the cathode was collected by displacement of the aqueous NaOH solution, transferred to an evacuated sampling vessel via a drying tube, and injected directly into the ionization chamber of a mass spectrometer. The signal at m/e $=28$, attributed to $\mathrm{N}_{2}^{+}$dominated the mass spectra. Weak signals attributed to water were also seen, and in one experiment a trace of ammonia was present. No peak at m/e $* 44$ for $\mathrm{N}_{2} \mathrm{O}$ was observed, although this species has been obaerved by others (2).

The amount of gas evolved at the cathode in these experiments was small, Less than $5 \mathrm{~mL}$, and the electrolyses proceeded slowly. For the coulometric experiments of Table 1 , in which the solutions were stirred and the cathode compartuent was flushed continuously with nitrogen or a nitrogen/oxygen gas mixture, reduction of nitrate was mach more rapid.

Increasing amounts of ammonia were observed upon an increase in the cathodic current density in bulk electrolysis experiments carried out at constant current. At current densities less than or equal to 0.107 amps $/ \mathrm{cm}^{2}$, nitrogen is the major electrolys is producf. At 0.466 amps $/ \mathrm{cm}^{2}$, ammonia was found to be the major electrolysis product. Also, the amount of ammonia was observed to increase during the course of the electrolyses.

$$
-5-
$$


Current efficiencies in Table 1 were calculated assuming that the products of the electrolyses were nitrite ion, a two-electron process, and dinitrogen, a five-electron process, using Eq. [3]

$$
Q_{T}=5 F\left(A_{0}-A_{t}\right)-3 F B_{t}
$$

to calculate the theoretical amount of charge for the nitrate reduction. In this equation $A_{0}$ is the initial amount of nitrate in moles and $A_{t}$ and $B_{t}$ are the molar amounts of nitrate and nitrite, respectively, present at the end of the electrolyais. The quantities were determined by ion chromatography. It can be noted from the data in Table 1 that observation of a nitrice intermediate was favored when platinum electrodes were employed. The Ni(Pt) electrodes, on the other hand, gave greater current densities based on geometrical electrode area and more efficient reduction to nitrogen gas.

Seversl preliminary electrolyses at constant current were performed in the presence of ruthenium added to the solution in the form of the disodium salt of hydroxynitroslytetranitroruthenium(II) $\mathrm{Na}_{2}$ [RuNO $\left.\left(\mathrm{NO}_{2}\right)_{4} \mathrm{OH}\right]$. Higher conversion rates of nitrate and nitrite inco amonia were observed in these experiments. Over the course of the electrolysis elemental ruthenium deposited on the nickel cathode. Since nitro and nitrosyl ruthenium complexes are known to undergo facile electrochemical reduction to amine complexes(5), the ruchenium complex and/or the ruchenium deposit on the cathode may in part be providing for a more facile mechanism for the reduction to amonia. 
Role of Oxygen.--Since previous studies were not concerned with the removal of dissolved oxygen gas in the electrolysis cells, several experiments were performed in which oxygen was mixed with the nitrogen gas which flushed the cathode compartment. It can be noted that not only was oxygen not removed from the cells in previous studies $(1-3)$, but that the solutions were saturated with the oxygen formed at the anodes. Since the reduction potential of oxygen is considerably less than that of the cathode during the reduction of nitrate, reduction of oxygen is likely to be involved in the cell process.

Results are shown in Figure 2 . Increasing the $z$ oxygen content has two effects. The current efficiencies decrease presumably due to the concurrent reduction of oxygen, and the rate of nitrate reduction, as measured by the $\%$ nitrate reduced in one hour of electrolysis, increases. The increase is significant, from ca. $45 \%$ for pure nitrogen to $90 \%$ for $5 \%$ oxygen in the gas stream. Several experiments were performed to see if hydrogen peroxide (e.g. $\left.\mathrm{HO}_{2}^{-}\right)$generated by the two-electron reduction of oxygen,

$$
\mathrm{O}_{2}+2 \mathrm{e}^{-} \mathrm{O}_{2}{ }^{2} \mathrm{H}_{2} \mathrm{O} \mathrm{HO}_{2}-+\mathrm{OH}-
$$

could be responsible for the increased rate of nitrate reduction. However, addition of aliquots of $30 \% \mathrm{H}_{2} \mathrm{O}_{2}$ solution to $\mathrm{NaOH} / \mathrm{NaNO}$ or $\mathrm{NaOH} / \mathrm{NaNO}_{2}$ mixtures at $80^{\circ} \mathrm{C}$ did not result in the decrease of the ion chromatagraphic peaks for nitrate or nitrite. These results suggest an electrocatalytic role for the superoxide anion, $0_{2}^{-}$, in the reduction process.

\section{INFORMATION ONIY :-}


Cyclic Voltammetry.--In spite of the high efficiency electrolyses of nitrate and nitrite solutions that have been performed, only nonideal cyclic voltammograms were obtained under similar experimental conditions. Careful attention to electrode pretreatment procedures were necessary in order to obtain reproducible behavior. The cyclic voltametric results only permit the qualitative conclusion that surface phenomena, e.g., adsorption processes and reduction of oxide films, play important roles in the electrode reaction for the reduction of nitrate/nitrite in NaOH media. Nonetheless, the voltametric data are presented here since they provide a framework for electrolysis experiments discussed above and a rationale for the selection of the experimental conditions for the bulk electrolyses.

1. Reduction of Nitrite. Figure 3 shows a cyclic voltamo-

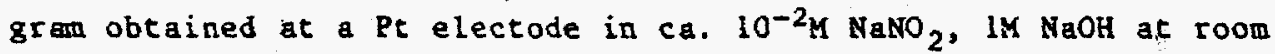
temperature in unstirred solution. On the forward, negative-going sweep a nearly symetrical nitrite reduction peak appears at -0.84 V vs. S.C.E. On the reverse sweep, the cathodic current increases, roughly retracing the forward current, and exhibits cathodic peak with a pronounced shoulder. This highly unusual voltametric pattern was reproducible and was observed for both nitrate and nitrite solution at platinum electrodes. The peak eurrent on the negative-going sweep was proportional to $\mathrm{v}^{0.7}$ over the sweep rate (v) range, 0.01 to $2 \mathrm{v} / \mathrm{sec}$. This behavior is indicative of a complex, nondiffusion controlled electrode process. Importantly, 
there is a wave at ca. $-0.3 \mathrm{~V}$ which is believed to be due to reduction of a platinum oxide film (see below).

The peak current was markedly dependent on temperature, increasing by a factor of seven over the temperature range $20^{\circ}$ to $95^{\circ}$ C. The plot of $\ln i_{p}$ vs $1 / T$ was nonlinear, which is further indication that a simple diffusion controlled process was not operative. Figure 4 shows the concentration dependence of the nitrite peak current. Again a nonlinear response is obtained with $i_{p}$ becoming independent of concentration as the concentration increases. The nitrite reduction curcent was not a strong function of the $\mathrm{NaOH}$ concentration as is seen in Figure 4 where the circles and triangles are for $1 \mathrm{M} \mathrm{NaOH}$ and $6 . \mathrm{IM} \mathrm{NaOH}(20 \%)$, respectively. Most of the electrolyses reported below were performed in $3 \mathrm{M} \mathrm{NaOH}$ with added $\mathrm{Na}_{2} \mathrm{CO}_{3}$.

Interestingly, the nitrite peak current was found to be dependent on the potential selected to poise the electrode prior to initiation of the negative-going potential sweep, the "activation potential", and the length of time the electrode was maintained at this potential. This behavior is shown in Figures 5 and 6 . The effect is quite dramatic as is seen in Figure 5. Potentiostatting the electrode at $0.5 \mathrm{~V}$ vs. S.C.E. for ca. 60 sec produces an increase in the cathodic reduction peak for nitrite of almost a factor of 10 . The peak current is also enhanced by simple immersion of the platinum electrode in the $\mathrm{NaNO}_{2}$ solution at open circuit (Figure 5), but longer times are required to enhance the current to the same level. 
The above observations, while not fully understood, are believed to be relsted both to adsorption of nitrite on the electrode surface and to reduction of surface oxide films formed at the positive potentials. The latter is indicated by cyclic voltamograms of platinum disk electrodes in 3 M NaOH solution in the absence of nitrite or nitrate. Potential excursions past $0.4 \mathrm{~V}$ vs S.C.E. result in the appearance of overlapping reduction waves in the -0.3 to $-0.6 \mathrm{v}$ region on the negative-going potential aweep that are dependent on the NaOH concentration. This behavior is shown in Eigure 7. Oxidation of the electrode at +0.5 V vs. S.C.E. produced a single reduction wave at $-0.43 \mathrm{~V}$ that increases as a function of the time the electrode is held the "activation potential," see Figure 7. When the potential is extended to t0.6 V to $+8.0 \mathrm{~V}$, a second reduction wave eppears at $-0.6 \mathrm{~V}$. It can be speculated that reduction of adsorbed oxygen or a thin oxide layer in the -0.4 to $-0.6 \mathrm{~V}$ region produces an active surface for the subsequent reduction of $\mathrm{NO}_{2}^{-}$at $-0.86 \mathrm{~V}$.

2. Reduction of Nitrate. At room temperature and concentration less than ca. 0.01M, cyclic voltamograms of nitrate at polished platinum electrodes showed very little indication of electroactivity due to a diffusion controlled process. At elevated temperature, however, a small reduction wave was evident in the cyclic voltammograms that had peak potentials and wave characteristics on the forward and reverse potential sweeps quite similar to the above description of the nitrate voltammetry. These peak 
currents, which increased with $\mathrm{NaNO}_{3}$ concentration, are attributed to reduction of $a$ nitrite intermediate or a comnon intermediate in the nitrate and nitrite reductions. The possibility of a nitrite iapurity in the $\mathrm{NaNO}_{3}$ at a sufficient level to give this behavior is discounted by the absence of a nitrite peak in the ion chromatograms of the initial nitrate solutions. "

At wore negative potentials and high concentrations of nitrate a broad voltametric wave due to nitrate reduction was observed; see Figure 8. The peak currents were dependent on the initial potential in a fashion similar to the nitrite voltametry, but the effect was less dramatic. Also the currents were dependent on the $\mathrm{NaOH}$ concentration, increasing with $\% \mathrm{NaOH}$ up to $12 \% \mathrm{NaOH}$ (ca. 3.4M) at which point the currents became independent of $Z$ $\mathrm{NaOH}$. At $20 \% \mathrm{NaOH}$ the currents did not vary with the carbonate content over the range $\mathrm{O}$ to $3 \mathrm{M} \mathrm{Na}_{2} \mathrm{CO}_{3}$.

Srali amounts of chromate were found to decrease markedly the voltametric current ascribed to the reduction of nitrate. During constant current electrolysis with nickel electrodes, the rate of nitrate reduction is decreased upon addition of chromate. A mole ratio of chromium to nitrate of $3.1 \times 10^{-4}$ is sufficient to inhibit the reduction of nitrate. It is believed that chromate is reoxidizing nitrite or lower oxidation state intermediates with the chromate being reduced to a Cr(III) species. Presumably, the $\mathrm{Cr}$ (III) species is reoxidized to chromate at the anode establishing a catalytic cycle. Further studies of this phenomenon with different electrode materials are in progress. 
At nickel electrodes cyclic voltamograms of nitrate solutions in NaOH displayed no well defined peak curcents, even a elevated temperatures. However, currents in the region of the cathodic discharge process were dependent on the nitrate concentration. A typical voltammogram of a $0.1 \mathrm{M} \mathrm{NaNO}_{3}$ solution in $3 \mathrm{M} \mathrm{NaOH}, 0.25 \mathrm{M}$ $\mathrm{NaCO}_{3}$ solution at $80^{\circ} \mathrm{C}$ is shown in Figure 9 . In view of the bulk electrolysis results described above and the concentration dependence of the voltametric behavior, the hysteresis evident on the reverse sweep in Figure 9 is related to the reduction of nitrate. The current difference at $-1.2 \mathrm{~V}$ between the current on the positive-going sweep and the current on the negative-going sweep was found to be strongly dependent on the nitrate concentration and the temperature as is shown in Figure 10.

The above results with platinum and nickel electrodes suggested the use of platinized nickel working electrodes. Much larger reduction currents and some definition of a voltammetric wave are evident in the voltamograms of nitrate of Ni(Pt) electrodes. At slow sweep rates $(30 \mathrm{mV} / \mathrm{sec})$ a peak current $\left(\mathrm{E}_{\mathrm{p}}=\right.$ -1.0) was evident in the voltamograms that had features 8 imilar to the nitrite peak voltamograms described above. Assignment of this wave to the reduction of nitrate or a nitrite intermediate in the nitrate reduction is supported by the electrolysis results presented above. 
A significant result of the voltametric study is that nitrite is easier to reduce than nitrate. This is consistent with the observation of nitrite as an intermediate in the bulk electrolyses.

\section{DISCUSSIOH}

The overall electrode reaction for the reduction of nitrate and nitrite under a variety of conditions in alkaline electrolyte solutions has been determined in this study. Previous work, which indicated that nitrate and nitrite in alkaline solution can be reduced at high current efficiencies to gaseous products, has been confirmed. This study has confirmed previous work that nitrate and nitrite in alkaline solutions can be reduced at high current efficiencies to gaseous nitrogen products. At platinized nickel cathodes using controlled pocential electrolysis techniques, in contrast to previous studies, only small or zero amounts of amonia were detected. This is presumably related to the significantly lower current densities used in the present study relative to the constant current electrolyges of others $(1-3)$. This should be an advantage in certain applications since reduction to nitrogen requires five equivalents of electricity while reduction to amonia requires eight equivalents. Furthermore, problems due to the generation of possible explosive mixtures of oxygen and amonia would be avoided. It can be noted that nitrogen was the wajor nitrogencontaining product in all of the electrolyses reported by Alter et al. (2). 
In the present study the largest voltammetric current densities were observed with the $\mathrm{Ni}(\mathrm{Pt})$ electrodes, $\mathrm{ca}+0.05 \mathrm{~A} / \mathrm{cm}^{2}$ of geometrical area. These levels are approximately an order of aagnitude less than those employed by Alter et al. who used Armco iron and cold rolled steel cathodes. They are also less than the current densities employed in the patent of Mindler and Tuwiner(1) where nickel electrodes were used. In the constant potential electrolyses, the current densities decrease with time and are much less than the above values at the completion of the electrolysis. In sumary, controlled potential electrolysis of alkaline sodium nitrate solution at $80^{\circ} \mathrm{C}$ using platinized nickel electrodes produces gaseous nitrogen at high current efficiency. Voltametric studies indicate that the electrode reaction involves surface phenomena and is not mass transfer controlled. Preliminary evidence suggests an electrocatalytic role for oxygen via the generation of the superoxide anion. While the nature of this role is not understood, it is clear that reduction of amall amounts of oxygen at the cathode is not deleterious to the performance of the cell.

\section{ACRMOKLEDGEMET}

The work performed at the University of Tennessee was supported by a contract from E. I. du Pont de Nemours and Company, Savannah River Laboratory. We wish to thank C. A. Chambers, who carried out preliminary ion chromatography on electrolysis solutions. 


\section{REFEREMCES}

1. Mindler, A. B. and S. B. Tuwiner, U. S. Patent No. 3,542,657, Nov. $24,1970$.

2. Alter, H. W., D. L. Barney, J. K. Davidson, A. C. Schafer, Jr., and F. J. Witt, "Electrolytic Recycle Method for the Treatment of Radioactive Nitric Acid Waste," Knolls Atomic Power Laboratory, KALP Report No. 1721, June 26, 1957.

3. Messing, A, E. and I. R. Higgins, "An Electrolytic Procedure For the Removal of Ruthenium and Nitrate from Alkaline Waste Solutions," Ozk Ridge National Laboratory, Report No. ORNL-2532, Sept. 19, 1958.

4. Horanyi, G. and E. M. Rizmayer, J. Electroanal. Chem., 188, $265(1985)$.

5. Murphy, W. R., Jr., K. Takeuchi, M. H. Barley, and T. J. Meyer, Inorg. Chem., 25, $1041(1986)$. 
IARLE 1

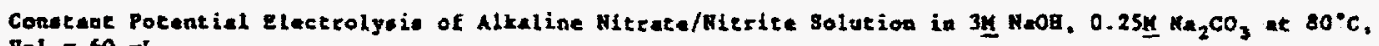
vol $=60$ al

\begin{tabular}{|c|c|c|c|c|c|c|c|c|}
\hline No. & $\begin{array}{l}\text { Electrode } \\
\text { Materisl }\end{array}$ & $\begin{array}{l}\text { Eapp1 }_{\text {app }} \\
\text { (Y.YS.S.C.E.) }\end{array}$ & Atmosphere & $\begin{array}{l}\text { Amounc of } \\
\text { NaNO, Reduced } \\
\text { (ms) }\end{array}$ & $\begin{array}{l}\text { Charge } \\
\text { Requited } \\
\text { (coul) } \\
\end{array}$ & $\begin{array}{l}\text { Current } \\
\text { efficiency } \\
(x) \\
\end{array}$ & $\begin{array}{l}x \text { Deer in } \\
1 \mathrm{tar} \\
\end{array}$ & Product \\
\hline 1 & $\mathbf{K i}$ & $0.5 v-1.35 v$ & $k_{2}$ & 99 & $\$ 62$ & 62 & - & $\mathrm{N}_{2}$ \\
\hline 2 & Pe & $0.5 v-1.15 v$ & $n_{2}$ & 36.3 & 293 & 70 & - & $\mathrm{NO}_{2}->\mathrm{N}_{2}$ \\
\hline 3 & Pt & $-1.2 v$ & $N_{2}$ & 99.4 & 702 & 80 & - & $\mathrm{N}_{2} \rightarrow \mathrm{H}_{2}$ \\
\hline 4 & $\mathbf{F t}$ & $-1.2 \vee$ & Air & 112 & 1196 & 53 & 48 & $\mathrm{~N}_{2}>\mathrm{NO}_{2}^{-}$ \\
\hline 5 & $\mathrm{Ni}(\mathrm{Rc})$ & $-1.2 v$ & $\mathrm{H}_{2}$ & 44 & 296 & 86 & 48 & $\mathrm{n}_{2}>\mathrm{NO}_{2}-$ \\
\hline 6 & $\operatorname{Mi}(F t)$ & -1.28 & $\begin{array}{l}y_{2}(997) \\
o_{2}(1 x)\end{array}$ & 71 & 547 & 74 & $7 !$ & $\mathrm{N}_{2}=\mathrm{NO}_{2}^{-}$ \\
\hline 7 & $\operatorname{Mi}(P \in)$ & $-1.2 \mathrm{v}$ & $\begin{array}{l}\mathrm{H}_{2}(95 \pi) \\
\mathrm{O}_{2}(5 x)\end{array}$ & 90 & 803 & 63 & 90 & $\mathrm{~N}_{2}$ \\
\hline 8 & $M i(P E)$ & $-1.2 v$ & $\begin{array}{l}N_{2}(91 \pi) \\
o_{2}(9 x)\end{array}$ & 90 & 1620 & 31 & 88 & $x_{2}$ \\
\hline 9 & $\operatorname{Hi}(P t)$ & $-1.2 v$ & $\begin{array}{l}N_{2}(83 x) \\
0_{2}(17 x)\end{array}$ & 84 & 1751 & 27 & 84 & $x_{2}$ \\
\hline 10 & $\mathrm{Ni}(\mathrm{PE})$ & $-1.2 v$ & Air & 91 & 988 & 53 & 54 & $N_{2}$ \\
\hline 11 & $\mathrm{Ni}(\mathrm{Rc})$ & $-1.1 \mathrm{v}$ & Air & 99 & 111 & 79 & 92 & $N_{2}$ \\
\hline 12 & $\mathrm{Mi}(\mathrm{PC})$ & $-1.0 v$ & Ait & 107 & 340 & 82 & 67 & $N_{2}$ \\
\hline 13 & $N_{i}(P t)$ & $-0.9 v$ & Air & 28 & 168 & 94 & 17 & $N_{2}$ \\
\hline 14 & $\mathrm{Ni}(\mathrm{Bt})$ & $-1.1 v$ & $\begin{array}{l}\mathrm{v}_{2}(70 x) \\
\mathrm{O}_{2}(30 x)\end{array}$ & 100 & 718 & 79 & 87 & $\mathrm{H}_{2}$ \\
\hline 15 & $\operatorname{Mi}(P t)$ & $-1.0 v$ & $\begin{array}{l}N_{2}(70 x) \\
O_{2}(30 x)\end{array}$ & 69 & 541 & 73 & 52 & $\mathrm{~N}_{2}$ \\
\hline 16 & $\operatorname{Ni}(p t)$ & $-0.9 v$ & $\begin{array}{l}a_{2}(707) \\
0_{2}(30 \pi)\end{array}$ & 53 & 266 & 79 & 20 & $\mathrm{~N}_{2}$ \\
\hline 17 & $M i(P t)$ & $\begin{array}{l}-1.1 v \\
\left(54^{*} \mathrm{c}\right)\end{array}$ & $\begin{array}{l}d_{2}(70 x) \\
0_{2}(30 x)\end{array}$ & $\$ 3$ & 432 & 78 & 88 & $\mathrm{H}_{2}$ \\
\hline 18 & $N(P t)$ & $\begin{array}{l}-1.14 \\
\left(25^{\circ} \mathrm{C}\right)\end{array}$ & $\begin{array}{l}\mathrm{H}_{2}(702) \\
\mathrm{O}_{2}(302)\end{array}$ & 36 & 314 & 64 & 14 & $H_{2}$ \\
\hline 19 & $\mathrm{Hi}$ & $-1.3 \mathrm{v}$ & $N_{2}(70 x)$ & 14 & 578 & 13 & 5 & $\mathrm{~N}_{2}>\mathrm{WO}_{2}^{-}$ \\
\hline 20 & $\mathrm{Ni}(\mathrm{Pt})$ & $-1.2 v$ & $n_{2}$ & $144^{b}$ & 540 & 88 & 94 & $x_{2}$ \\
\hline 21 & $\mathrm{~N}(\mathrm{PC})$ & $-1.1 \mathrm{~V}$ & Aix & $100^{b}$ & 491 & Bs & 97 & $N_{2}$ \\
\hline
\end{tabular}

a) Electrolysis at $0.5 \mathrm{~V}$ for $20 \mathrm{kec}$, followad by electrolysis ac -1.394 for 100 sec.

b) Weight of $\mathrm{NaWO}_{2}$ 


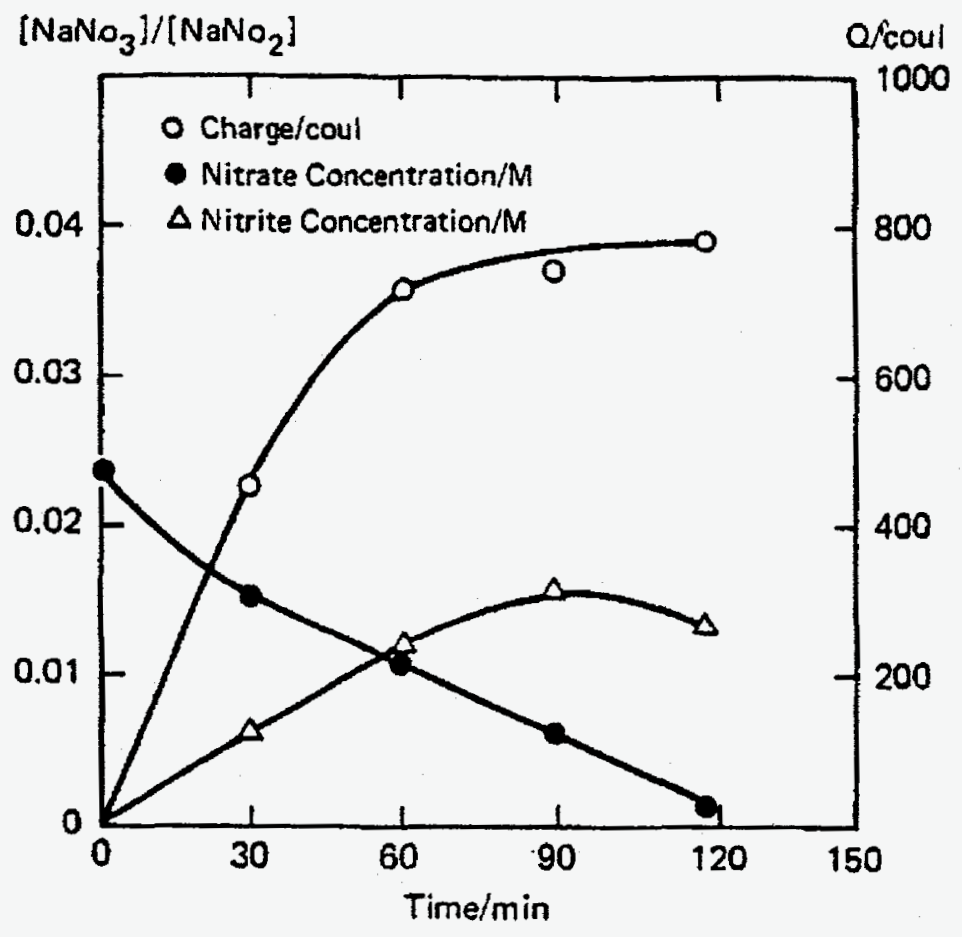

FIGURE 1. Varietion of Nitrate and Mitrite Concentratione during Electrolyois of $\mathrm{RaHO}_{3}$ in $3 \mathrm{M} \mathrm{HaOH}, 0.25 \mathrm{M} \mathrm{NaCO}$ at a $\mathrm{Ni}$ (Pt) Electrode; $-1.2 \nabla$ Fs S.C.B.; $80^{\circ} \mathrm{C}$ 

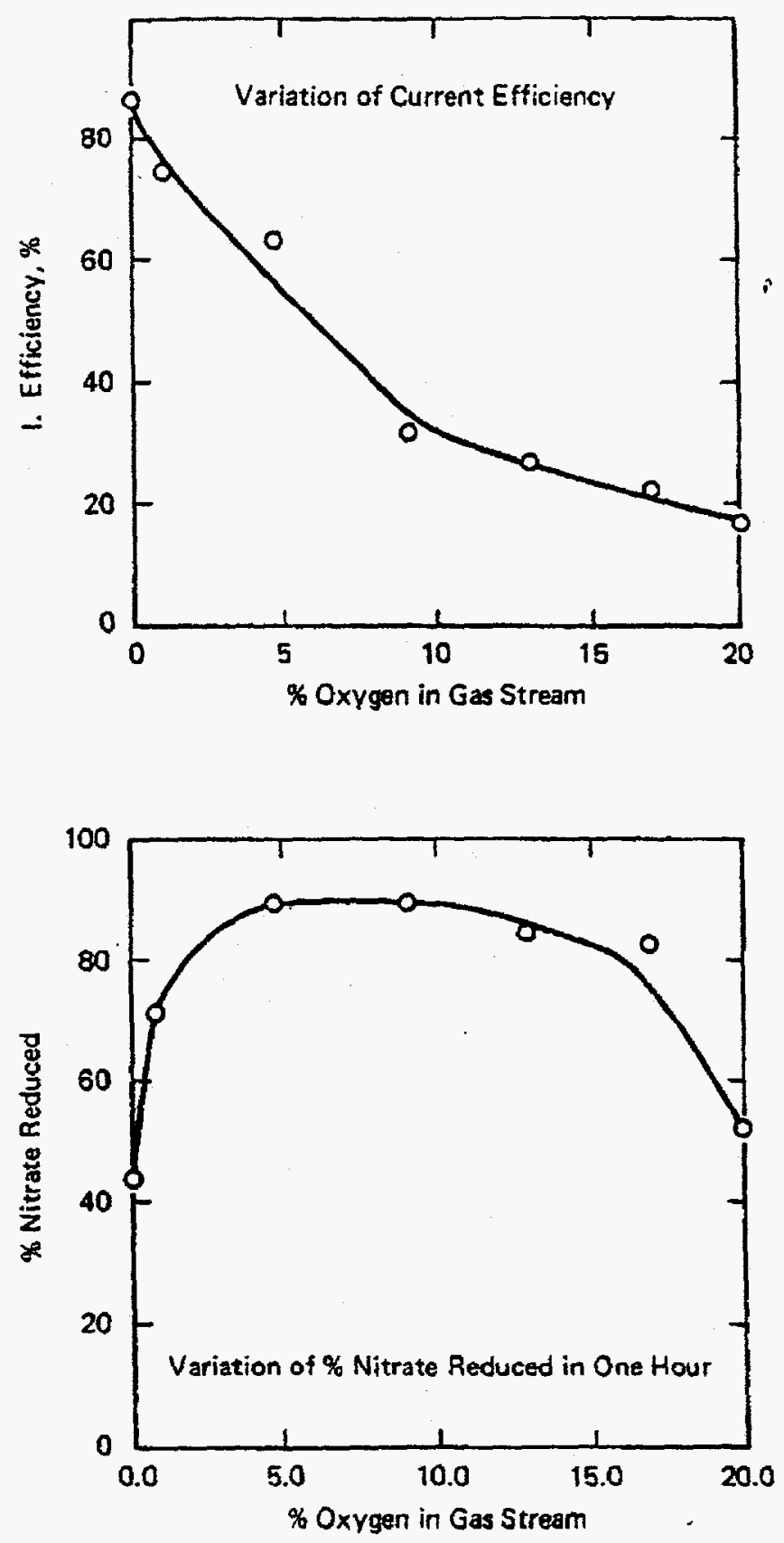

FIGURE 2. Effect of Oxygen on Cachodic Electrolgeis of Nitrate Solutions at $80^{\circ} \mathrm{C}$, in $3 \mathrm{MHaOH}, 0.25 \mathrm{M} \mathrm{Na}_{2} \mathrm{CO}_{3}$ at a $\mathrm{Mi}(\mathrm{Pt})$ Electrode 


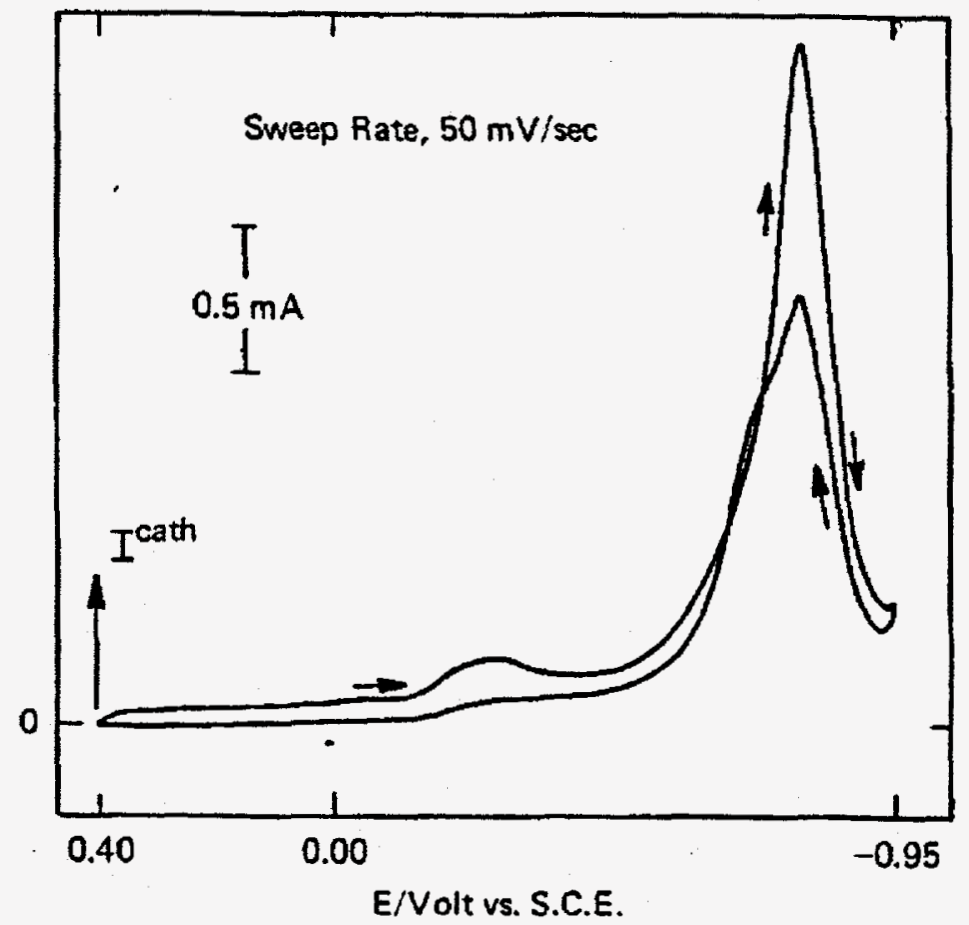

FIGURE 3. Cyclic Voltangran for the Reduction of 0.015 Mitrite at $23^{\circ} \mathrm{C}$ in $1 \mathrm{M}$ RaOH; Platinum Blectrode 


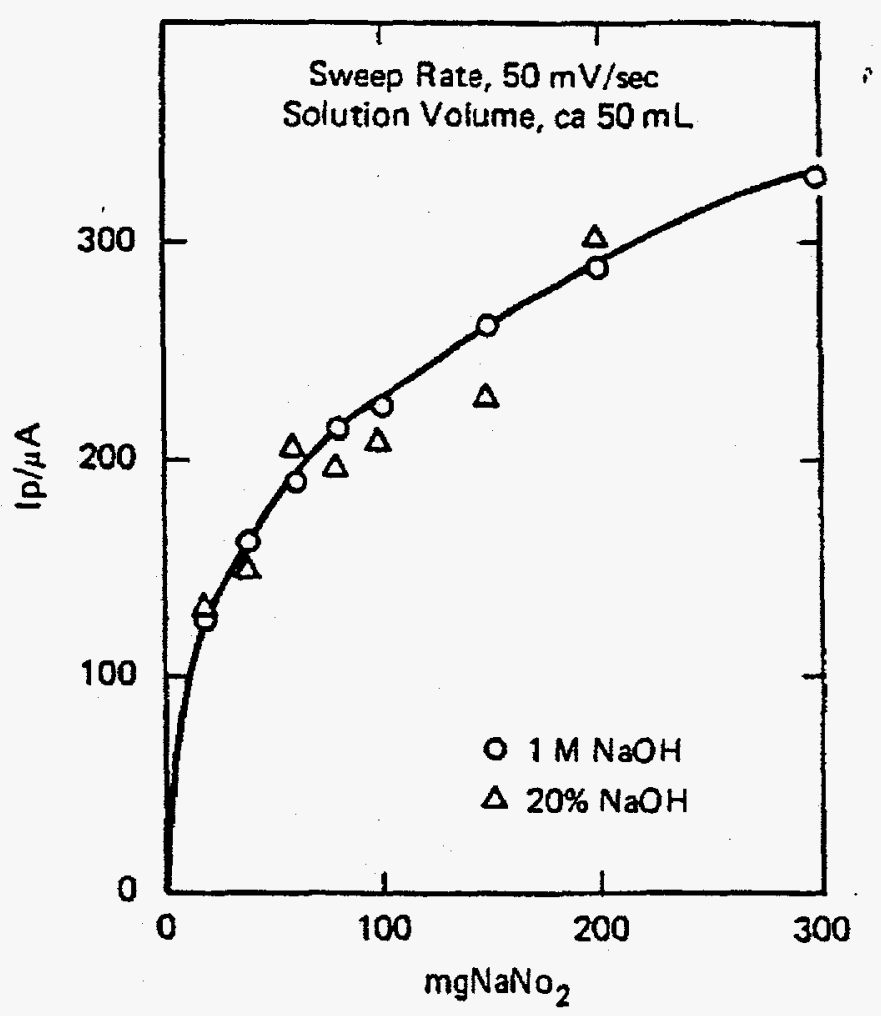

PIGURE 4. Veriation of the Peak Current for the Reduction of Mitrite in IM RaOH and in $202 \mathrm{KaOH}$; Platinum Blectrode 


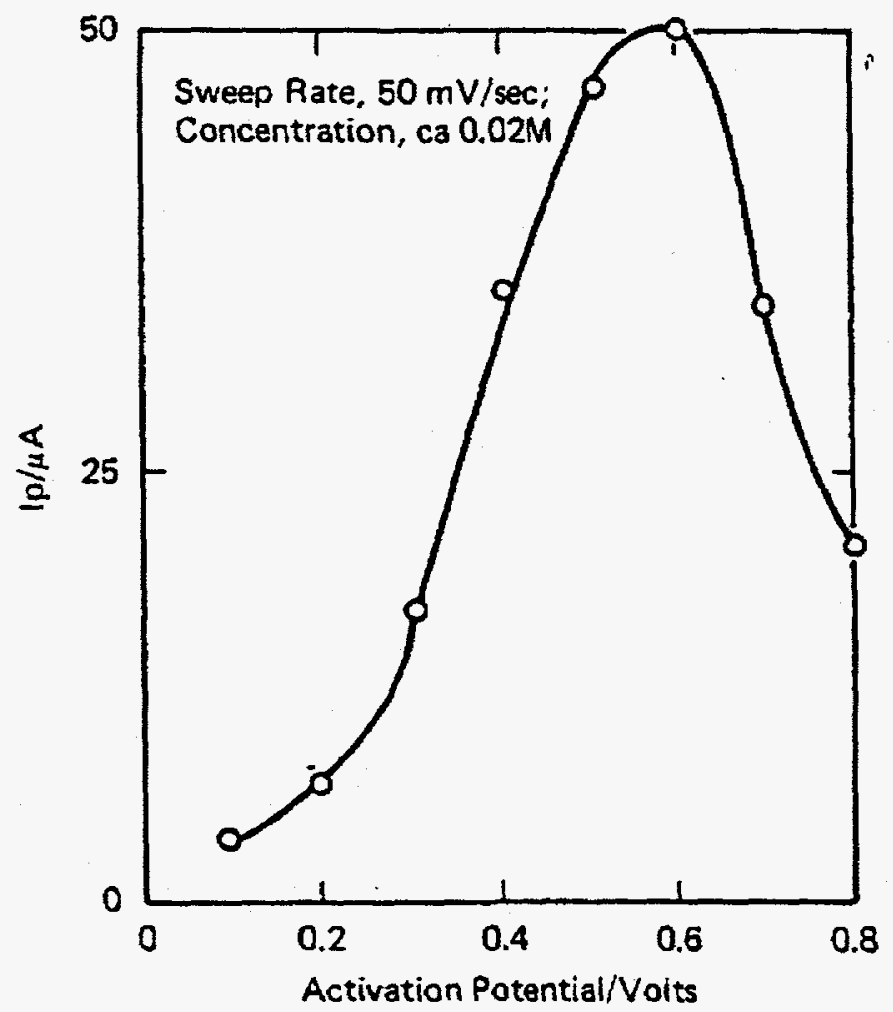

FIGURE 5. Variation of the Mitrite Voltametric Peak Current in 1M NaOB with Initial Potential ("activation potentiol") 


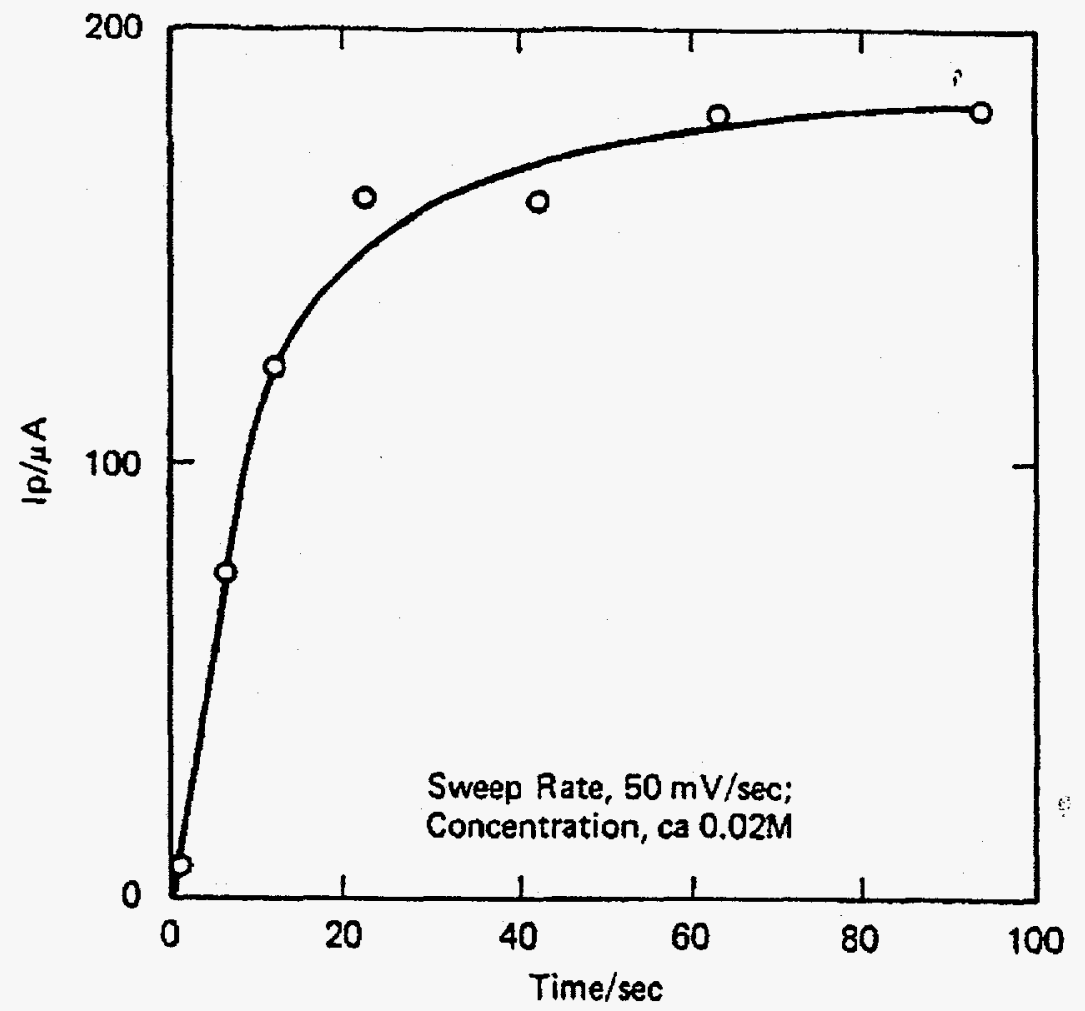

FIGURB 6. Variation of the Kitrite Votammetric Peak Current in $1 M$ NaOB with "Activation Potential" Pulse Tine 


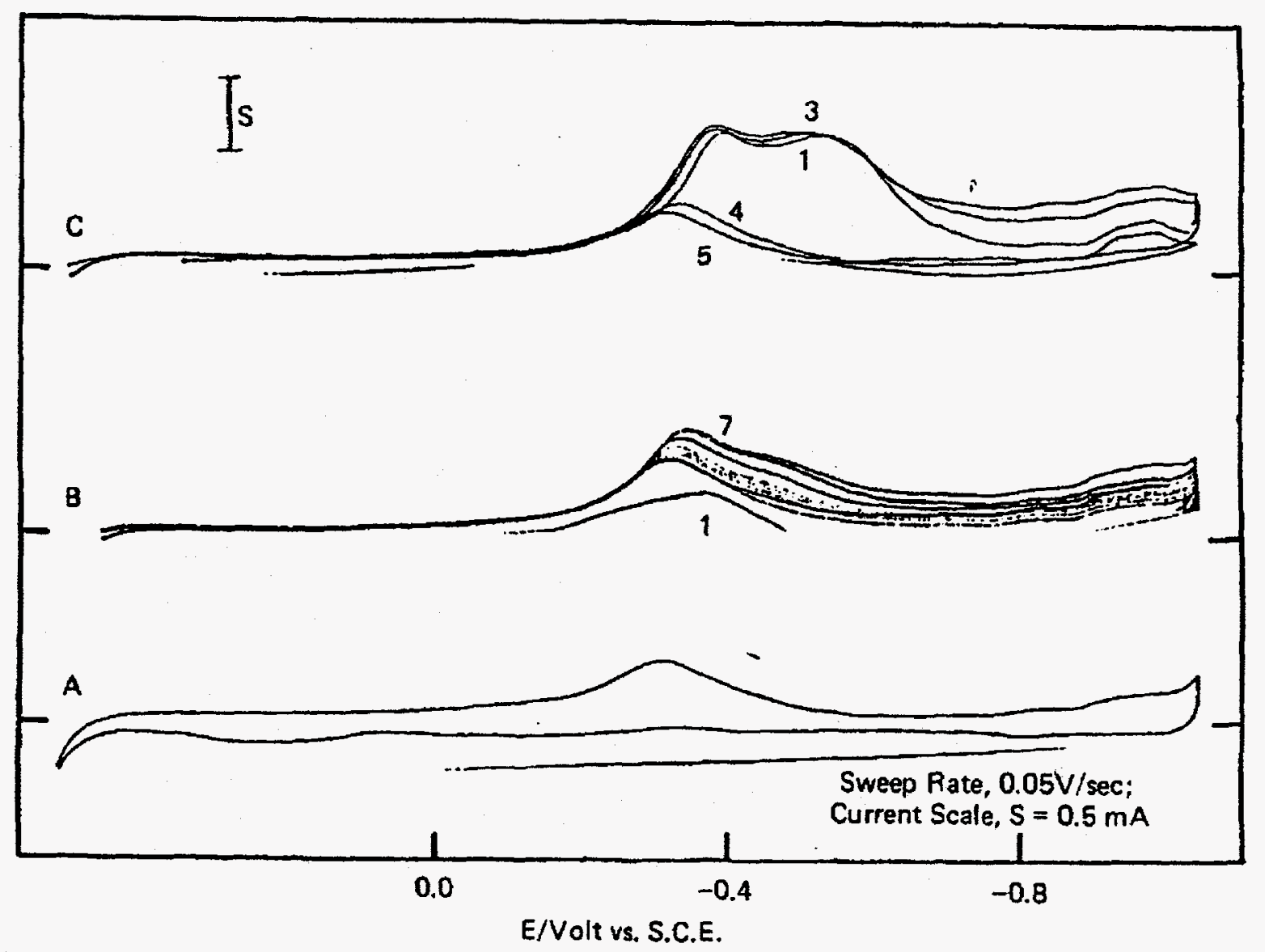

A Steady-State Cyclic Voltammogram

B Linear-Sweep Voltammograms with "Activation" at $+0.5 V$ vs. S.C.E. for $(1-7) 5,10,20,30,40,50,60 \mathrm{sec}$

C Linear-Sweep Voltammograms with Initial Potential $=+0.8,+0.7,+0.6$, $+0.5,+0.4$ V vs. S.C.E. for Curves 1.5

FIGURE 7. Voltatomogram of 3Y XaOH, $0.25 \mathrm{Y} \mathrm{Ha}_{2} \mathrm{CO}_{3}$ at Platinum $\left(0.21 \mathrm{~cm}^{2}\right)$; Temperature, $80^{\circ} \mathrm{C}$ 


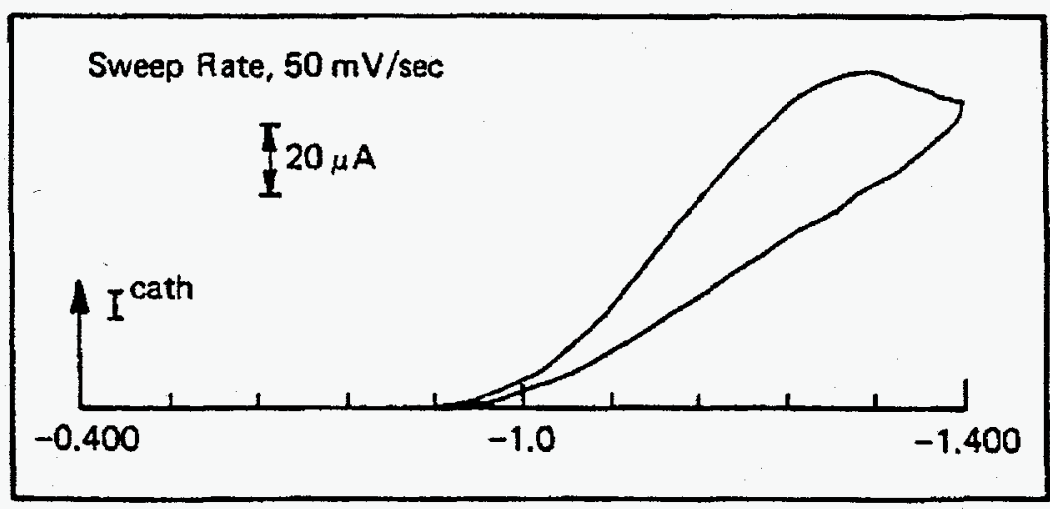

E/Volt vs. S.C.E.

FIGURB 8, Cyclic Volt ammogran of $0.59 \mathrm{M} \mathrm{NaNO}_{3}$ in $3 \mathrm{M} \mathrm{MaOH}, 0.25 \mathrm{M}$ $\mathrm{Na}_{2} \mathrm{CO}_{3}$ at $80^{\circ} \mathrm{C}$ 


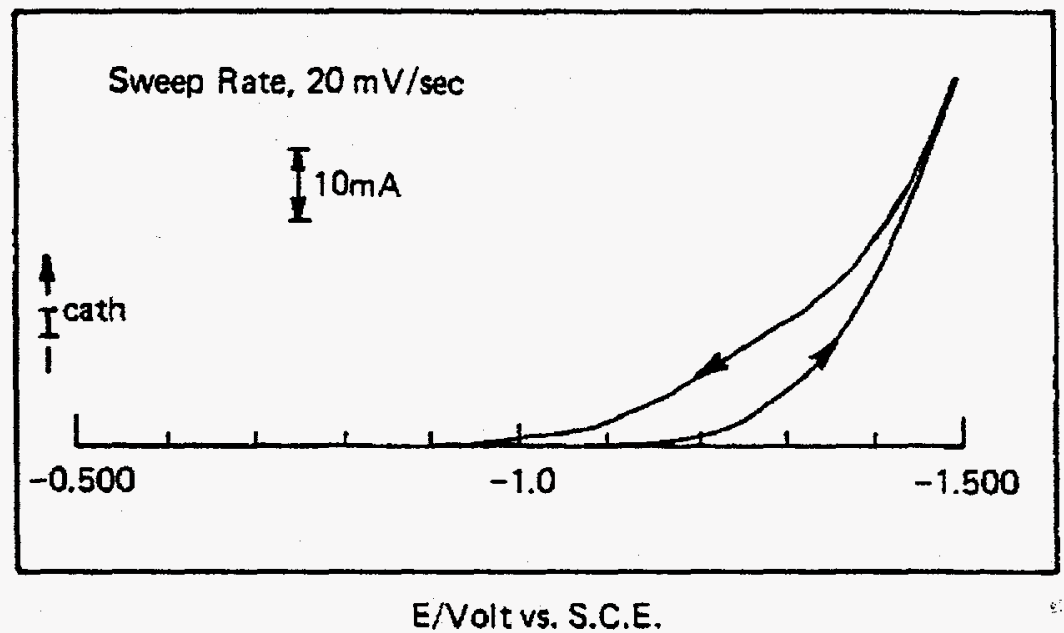

7IGURs 9. Cyclic Voltamogran of $0.39 \mathrm{M} \mathrm{NaHO}_{3}$ in $3 \mathrm{M} \mathrm{NaOB}, 0.25 \mathrm{M}$ $\mathrm{Ha}_{2} \mathrm{CO}_{3}$ at $80^{\circ} \mathrm{C} i$ Hickel Blectrode 


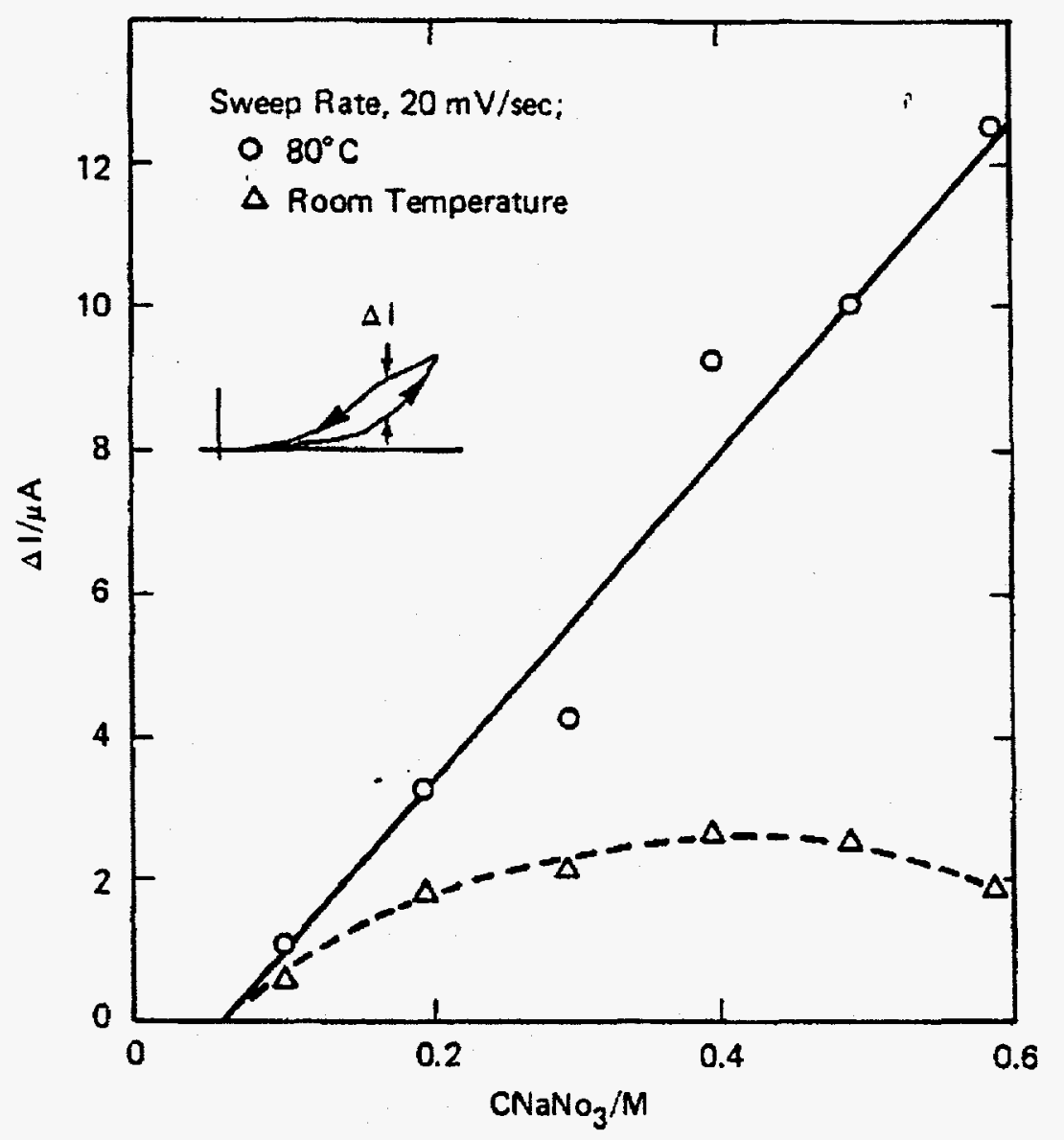

FIGUBB 10. Variation of I at Nickel Rlectrode vith Concentration of $\mathrm{HaHO}_{3}$ in $\mathrm{MaOH}$ at $80^{\circ} \mathrm{C}$ 